\title{
呼吸湿度に関する研究: 給湿器の効率について
}

\author{
嗞山大学医学部第二外科教室 (主任 : 砂田輝武教授) \\ 佐藤暢
}

[昭和 35 年 11 月 2 日受稿]

\section{I. 踷 言}

酸素治缭や麻醉において，患者に吸入させるガス に十分な湿度を与えることの重要性は広く認められ ており,そのために種々な給湿器 (Humidifier or Water Vaporizer) が日常用いられている. 本邦で 普及しているものには, ありあわせの瓶に水を入れ その中につつてんだ棒の先から bubble させるよう な簡単なものが多いがなかにはかなり複雑な工夫 を施したものもある。

著者は，日常術後患者や正症患者の管理にあたつ て、吸入ガスへの給湿の問题はゆるがせにできない ことを痛感するとともに，一方ではこれはど大切な 秴湿器の効率について従来ほとんど究明されてない のに気付いたので，給湿器の構造や使用条件とそ の給湿効果との関係を研究した．との方面での文 献1)-9)を検索してみても，理学工学方面での一部の 特殊な研觉があるばかりで, 医学的な実用面で参考 になるものは全くなくまた医療器械の供給者側も 使用者㑡すただ慢然と習惯的に在来の方法に甘んじ ていたのは，主にこのような湿度を測定する適当な 方法10)-12）がなかつたからと思われる. 湿度に関す る研究は従来一般に立ち達れているといわれている か，医学方面もちの例外ではない，著者は新しい湿 度测定法を用いて㭔吸湿度に関する一速の研究を進 めているが、こてではその一部として bubbling を 中心とした給湿機構について種々検討を加えた。

\section{II. 菱是および方法}

湿度の椡定には, 岡山大学理学部坂手邦夫助教授 らによつて咞笁された光電管式自動露点湿度計（以 下単に露点計と略す）を用いた，ての計器は元来工 業計器として考案されたすのであるが，著者はこれ を医学生物理学分野での研筞でも実用化して, 従来 は不可能とされていた種々な湿度の精密測定にはじ めて成功した。本露点計の原理, 瞥造, 性能などの 詳紐は先の発表(2)-17) にゆずるが，要は被測定気体
に触れる鏡面上の露の量が增減しないような湿度を 光要管を用いて自動的に求め，その冷却と加熱の釣 合つた状態における鏡面温度を熱電対で測るととに よつて，その気流の露点を自動的に迫跡できるよう にしたものである．かかる測定においては，その気 体の温度を同時に測定することが，それ自体生体に とつて重要な因子としてのみならず，露点との関倸 から関係湿度を算出するため江是非必要である，給 湿された気体の温度を測定するためには，給湿装置 を通過したガスを導くパイプ内等電対を仕込み， その後で簬点計に導いて露点を测定した，簬点から 表1118)により飽和蒸気压および絶対湿度をただち に求めうる. 一方給湿装置の条件として，給湿装喕 にはいる前の気流の溫度, 給湿装置内の水温, 周囲 の気温を測定するためにもそれぞれ熱電対を装置し た。これらの熱電対はすべて、露点計の鏡面温度測 定用の熱電対と同種の銅一コンスタンタン熱電対で あり，切换えスイッチで共通の電子筸式自怔平衙計 器（鳥津 ARP-21 型又は SAP-21 型を使用）に連 結して，温度および蕗点が連続自記できるようにし てある。このようにすれば，各測定値阔の比校に便 利である。また，水温と気温は水銀寒暖計でむ測定 して, 熱電刘による测定值と比校検討した.

第 1 図は装置全体の概略を示す。(1)は酸䋕ボン

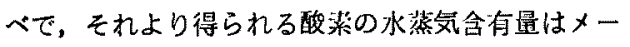
カーによれば 0.2 Vol. 96以下である. この酸少を 減王弁を通じてロタメータ式流量計(2)に等く（3） は給湿装憕へ導くガスの温度を変化さして実駼する ための冷却槽であるが，特に必要と寸る埸合以外は

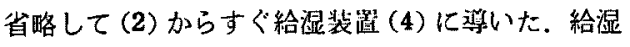
装瑟としては，一般に用いられているもののほかに， 水湓，水泳，孔の数や大きさなどの諸因子を檑々に 交えて実験できるものを自作した。

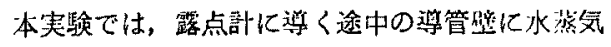
が凝結して湿度の测定に愦差を生ずるのを滓けるた め,ガス温, 水滥ともに常にその㭙の気滥より离く ない籍团で行つた，一般に用いられている状態です 


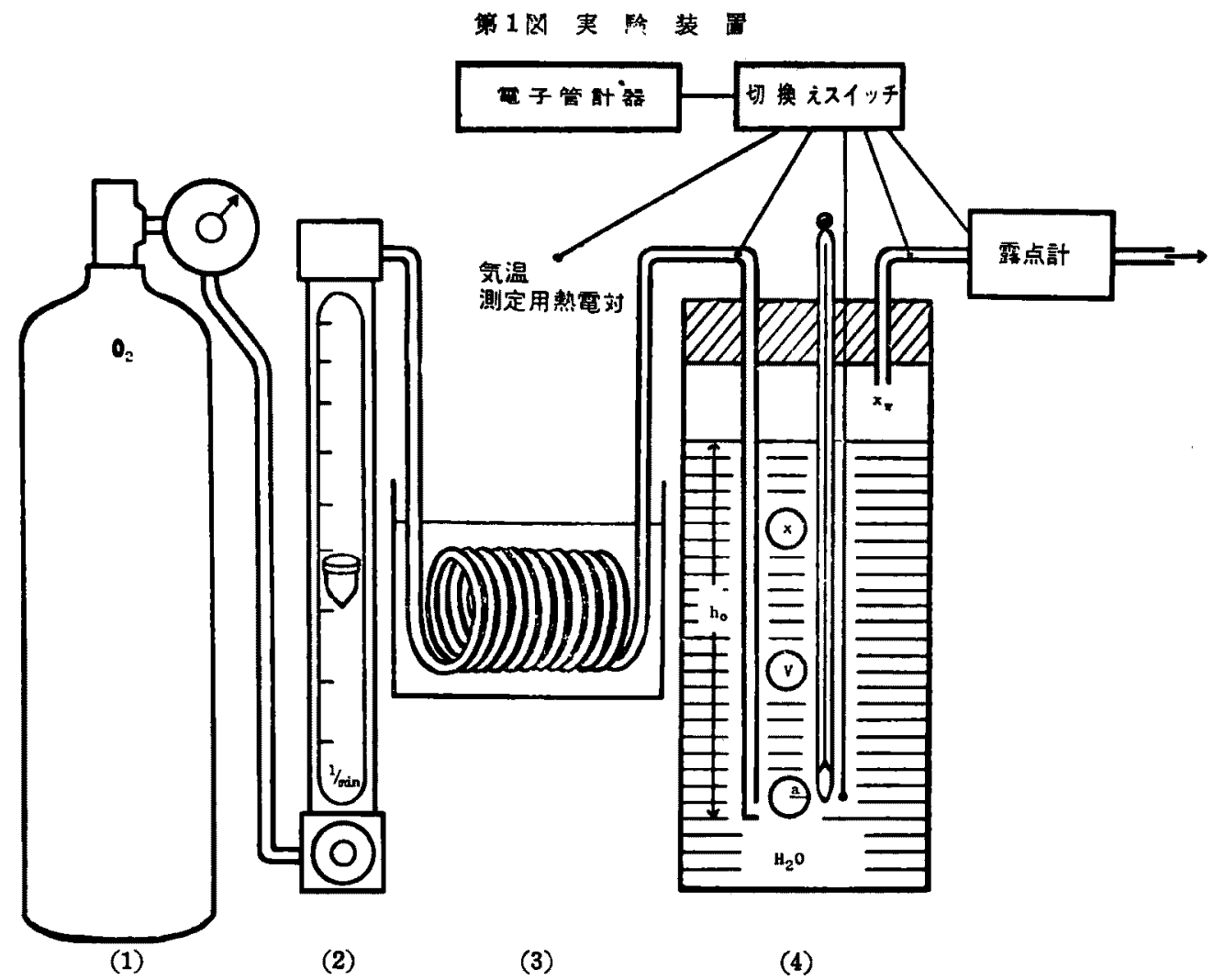

同様の条件であるから，実用性を検討する目的には これで十分であると考えられる。

\section{III. 研 究結 果}

\section{1、軘通に使用する条件での実倹}

1）市販のガラス製三角コルベン型給湿装置.と れは容量 200 300 cc の三角コルベンに適当量の水を いれ，長短二本のガラス製または金属性の管を通し たガラス慗またはゴム製の栓をして，その長い方の 管の先加ら酸装を水中に bubble させ，水面上に出 るまでに給湿されたガスを短い方の管から㐿出して 用いるあのである。第 1 表はてれを用いた実呀の 1 例である. 内径 $6 \mathrm{~mm}$ のガラス管の先端から水樑 $2 \mathrm{~cm}$
のところで下向けに bubbl=する，その時の気温は $25.0^{\circ} \mathrm{C}$ で, 水温は当初 $21.7^{\circ} \mathrm{C}$ であつたのか実験中 に20.5 $\mathrm{C}$ まで下降した。 給湿されたガスの温度に おりる飽和水菽気圧と ${ }^{18}$ 露点の飽和水蒸気圧加算 出したのがそのガス自体の関係湿度 (R. H.)であり， そのガスが生体に吸入された場合に体温まで温めら れるとして，生体位対しての関係を求めたものか

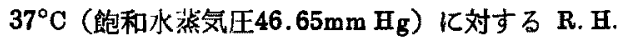
である.

2）直径 $7 \mathrm{~cm}$ のガラス瓶に約 $300 \mathrm{cc}$ の水を入れ， 直径 $2 \mathrm{~mm}$ の孔 1 個加ら横向きに bubble さす自家 製給湿器. 水梁を $1 \mathrm{~cm}, 4 \mathrm{~cm}, 7 \mathrm{~cm}$ 之変元, 各水樑保 ついて酸溸流量を $1 l /$ 分から $8 l /$ 分まで变化さした

第 1 表 鈴木式吸入用コルベンの給湿勃果

\begin{tabular}{|c|c|c|c|c|c|c|c|c|}
\hline \multicolumn{2}{|c|}{$\mathrm{O}_{2}$ 流量 $(l / \mathrm{min})}$. & 1 & 2 & 3 & 4 & 5 & 6 & 7 \\
\hline \multirow{3}{*}{$\begin{array}{l}\text { 給湿され } \\
\text { たガスの }\end{array}$} & 温 度 $\left({ }^{\circ} \mathrm{C}\right)$ & 24.6 & 24.4 & 24.0 & 23.7 & 23.4 & 23.3 & 22.7 \\
\hline & 簬 点 $\left({ }^{\circ} \mathrm{C}\right)$ & 19.7 & 20.0 & 19.9 & 19.7 & 19.6 & 19.4 & 19.3 \\
\hline & R. H. (क) & 74.2 & 78.5 & 77.9 & 78.3 & 79.2 & 78.7 & 81.2 \\
\hline \multicolumn{2}{|c|}{$37^{\circ} \mathrm{C}$ に対する R.H. (写) } & 36.5 & 37.2 & 36.9 & 36.5 & 36.3 & 35.8 & 35.6 \\
\hline
\end{tabular}


第 2 因給湿に括ける給湿器内の水温 ( H $_{2} \mathrm{O}$-t. )，給湿されたカスの温度 (Out-t.)，

露点 (d. p.)，関係湿度 (R. H.) の变化

$1 \mathrm{~cm}$

Depth of Water for Bubbling

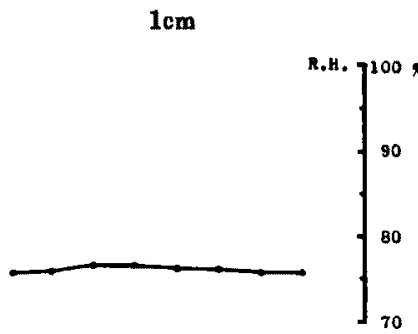

$4 \mathrm{~cm}$
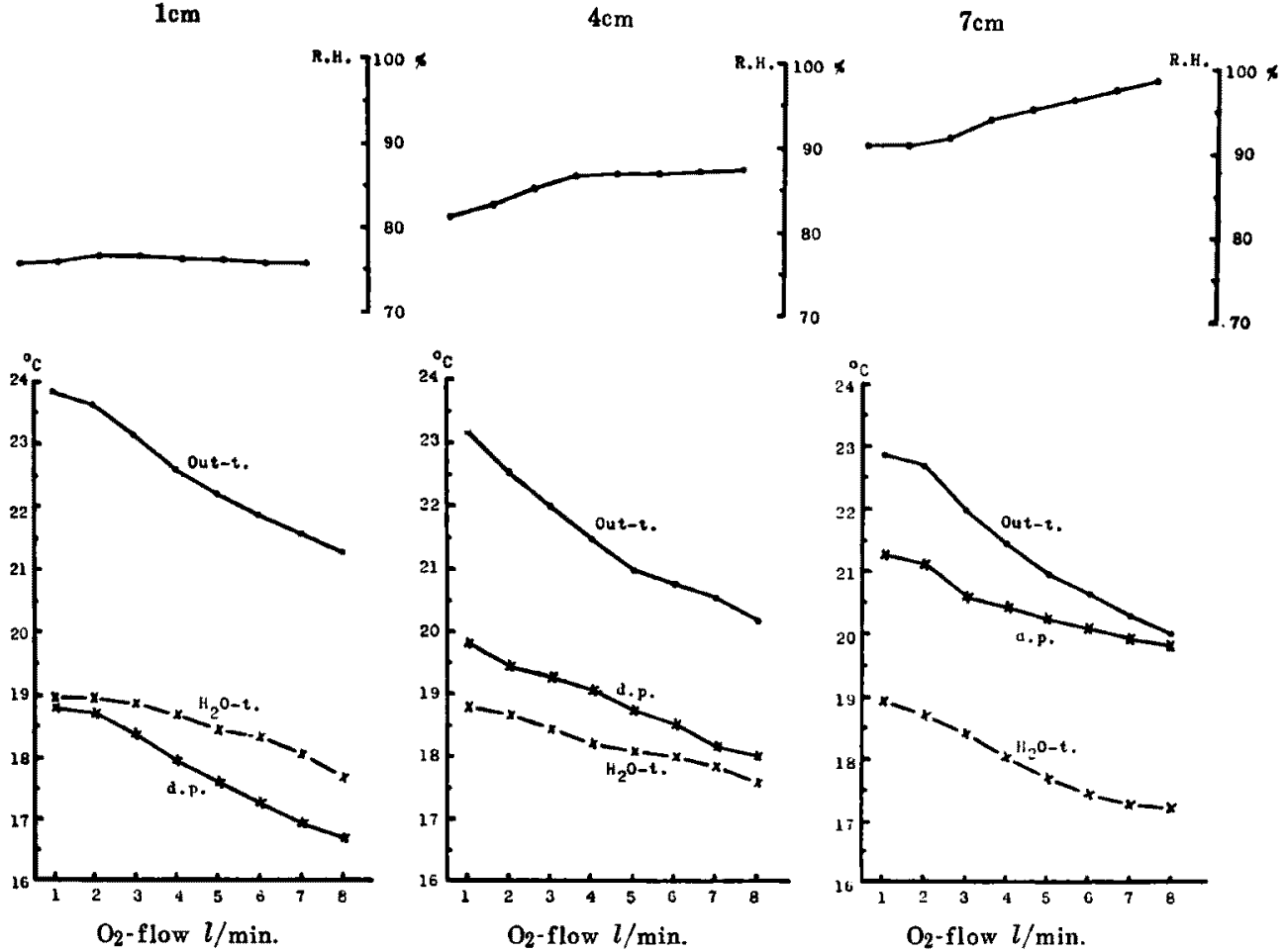

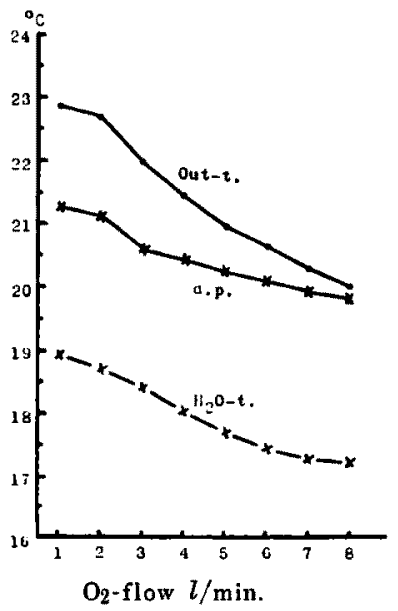

時の水温 ( $\mathrm{H}_{2} \mathrm{O}$-t.)，給湿されたガスの湿度 (Out-t.)， 露点 (d. p.)，関係湿度 (R. H.) を示すと第 2 図の ようである。気温は $24^{\circ} \mathrm{C}$ であつた。

小括および考按

3）気泡式エーテル気化器 (T. I. 製) を給湿用に 䎐用したもの．との装罩では円船の周辺にある無数 の小さいれ（直径0.1 $\mathrm{mm}$ 以下）から bubbleするの で, 有勃な給湿器として著者らは爱用している，ガ ラス瓶に約 $20 \mathrm{cc}$ の水を入れ，丹盤加ら上の水深を $1,3,4,8 \mathrm{~cm}$ と変えて，1 8 $l /$ 分の酸䋈を流して得ら れるガスの路点を测定すると第 2 表のようである。 その時の気澏は $21.2^{\circ} \mathrm{C}$, 水温は $18.5^{\circ} \mathrm{C}$ から $16.3^{\circ} \mathrm{C}$ の間であつた。

1）において，酸姳流量を增すにつれて露点が下 つている，つまり絶対湿度は减少する，しかしガス

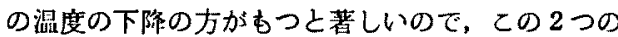
関係加らがス自体の関係湿度を求めると，高流星は どかえつて上昇している．しかし生体に対して考え る時には，高流星ほ上゙ガスの鼬度は低く湿度も低く なるのでやはり好ましくないと考えられる，実験中 に水温が $1.2^{\circ} \mathrm{C}$ 下降したのは水の気化㷊による。

2）においても，全般に 1) と同樣な变化が見ら れる. 水樑の変化によつては，深い所から泡立つほ ど気泡加水に触れる時間が長いので，露点は高い，

第 2 表 エーテル気化器（T.I. 製）による給湿効果，(露点 ${ }^{\circ} \mathrm{C}$ )

\begin{tabular}{|c|c|c|c|c|c|c|c|c|c|}
\hline \multicolumn{2}{|c|}{$\mathrm{O}_{2}$ 流 量 $(l / \mathrm{min})}$. & 1 & 2 & 3 & 4 & 5 & 6 & 7 & 8 \\
\hline \multirow{2}{*}{ 水 } & $1 \mathrm{~cm}$ & 19.2 & 19.3 & 19.2 & 19.1 & 18.6 & 18.3 & 17.6 & 17.2 \\
\hline & $3 \mathrm{~cm}$ & 19.2 & 19.2 & 19.0 & 18.7 & 18.6 & 18.2 & 18.0 & 17.6 \\
\hline \multirow{2}{*}{ 深 } & $4 \mathrm{~cm}$ & 19.9 & 19.9 & 19.5 & 19.4 & 19.3 & 19.2 & 18.8 & 18.6 \\
\hline & $8 \mathrm{~cm}$ & 18.7 & 18.6 & 18.4 & 18.3 & 18.1 & 18.0 & 17.9 & 17.9 \\
\hline
\end{tabular}


特に高流量での露点下降が少ない，一方ガスの温度 は水深の大きいほど水温の影響を受ける時間が長く， さらに水の気化熱による冷却も加わつて下り方が大 きい，したがつて水深が大きいと関係湿度が高くな るが，特化高流量で上开する。

3）においては給湿効果がよく，ガス温との差を 計つてもいずれも $0.6^{\circ} \mathrm{C}$ 以下であつた。 したがつて 関係湿度を計算してあ常に95\%以上であるが，ての 梯な成績については後に詳述する，この装置では一 般に流量を增してあ露点の下降が少ないか，とくに 水深が大きいほど高流量での下降が少ない。

以上の実験ではいすれ使用する水の温度が気温 よりるかなり低い，乙机は日常使用する時のように， 水道水を䅂湿器に入れて間もなく使用したからであ る. 水温は室温によつて上昇し，気化熱によつて下 降するから，实験中たえず変動する，したがつてが スの温度と水洫の差も一定しない。

この様な方法では，多くの因子が同時に変現して いるので，各々の因子の占めの役割りを明暸に知 るととができい，そこで，以下では実用する状態 とは異なるが，給湿の条件となる因子として，(1) 周囲の気温，(2)給湿器にはいる前のガス温，(3)水 温，(4)水深，(5)孔の向き，(6)孔の大きさ，(7)喷 出孔の数，(8) 水の性状（粘性など），(9)ガスの流 量などについて各因子の影響がなるへく別々にわか
ろように実験を工夫した.

\section{2. 気温，給湿器にはいる前の酸素ガスの温度变} 化 およびその影零

酸菜ボンベは室温に長く放置したあのを用いたの で，得られる酸素ガスの温度はそこの気温に左右さ れる，ただしボンへ内に压綟してある酸菜を減圧胿 脹して用いるので,ガスの温度は気温より多少低い のが普通である，そしてその温度下降は高流量を用 いる時ほど著しい，著者の測定では， $1 l /$ 分と $8 l$ 分の流量におりる酸浆ガスの温度差は最高 $3.3^{\circ} \mathrm{C} \mathrm{K}$ 及んだが，て机はその時までの使用による诚圧并や 䢘出ゴム管の冷却之周囲からの加温で左右されるの で，常に变動して一律にはいかない.そとで各実験 ごとに給湿器にはいる前のガス温を測り，その値を その都度示すことにした。一般に導管を長くして実 験を手早くすますならば，その変動を少なくするて とができる。

第3図は，流量を1l/分から1つつつ增して $8 l /$ 分 に至り，ついで逆に1l/分まで減しながら実験する 時, 給湿前のガス温 (In-t.)，給湿後のガス温 (Out-t.) およびその蕗点 (d. p.) の変化する状態を示す. 往 復とも In-t. は高流量で下つているか，更にこの実 験は時間をかけて (全释過16分) 行つたので咸圧弁 や導管の冷却につれて同流量においても往より復の 方が低くなつている。 Out-t. の変化も同様であるが，

第 3 図給湿前のカス温とその影整

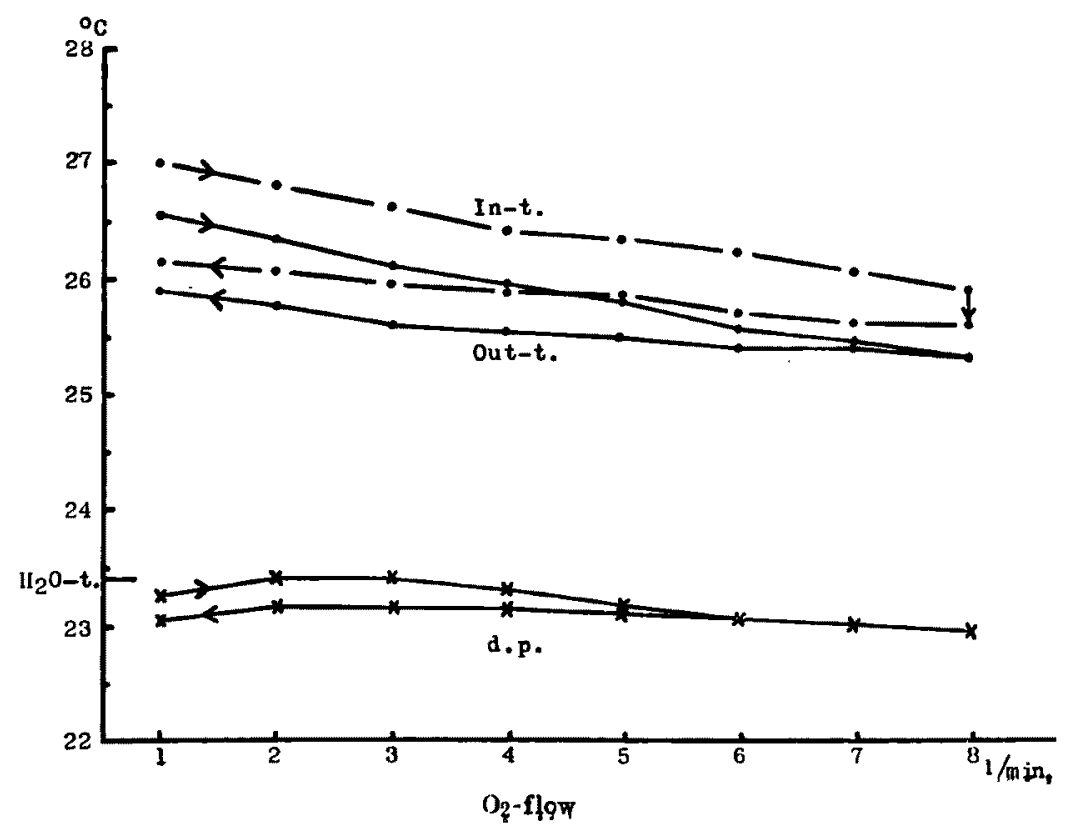


往復の差は In-t.のそれより小さい. d.p.の変化は 更に少ない，乙の場合水温は恒温槽により一定に保 5、給湿器は直径 $2 \mathrm{~mm}$ の孔 3 個加ら水深 $5 \mathrm{~cm}$ の所 で水平比 bubbleさした。

つぎ第 1 図（3）の装監を用いて給湿器にはいる 前のガスを命却しながら実験すると，In-t. が下降 するにつれて，Out-t., d.p., 水温はいずれも下降す るが，その程度は In-t. の下降の程度に較へて非常

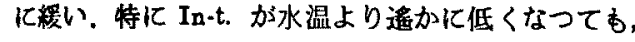
Out-t. およびd.p. はあまり下らず，水温の影響が 正㨽的であると云える.

\section{3. 水温の影䨌}

1.にみられるように水温が絶えず変化すると， 各因子の影飄が分析できないので，以後の実験では 水温を一定さすように工夫した，たとえば大きな気 化瓶を用いて $3 l$ 以上の水を入れしかも気温にでき るだけ近ずけてから用いれば，一連の実験を行う問 では水温の変化は問題とするにたらない，また気化 瓶が小さくてす，大きい恒温槛の内に入れて実験す れば同様の結果をうる尌ができた。一方この後者の 方法を用いて，給湿器内の水温を変化さしその影響 を調へた。給湿器は直径 $4 \mathrm{~mm}$ の孔 1 個から下向き 飞 bubble さす構造であり, 気温は $32.5^{\circ} \mathrm{C}$, 給湿器 にはいる前の酸素ガスの沿度も $32.5^{\circ} \mathrm{C}$ で一定であ つた。第 3 表は程々な水濯での, 給湿後のガスの湿 度, 露点, 関係湿度を示す。

これによれば，水温が下降するにつれて，給湂後 のガスの温度る，露点む共に下るが，特に後者の下
降の方が著しい，従つてガス自休の関係湿度も下る 傾向にある．今とれを人体に吸入さす場合について 考えると(考案参照)，水温がそのガスの温度およ び湿度に圧倒的な影響を及群すことが明瞭である。 ガス温と水温が両者とも下降した膊は，2.と3.の 第3表 水温の歌㧞

\begin{tabular}{|c|c|c|c|c|c|}
\hline \multirow{2}{*}{$\begin{array}{l}\text { 水 } \\
\text { 温 } \\
{ }^{\circ} \mathrm{C}\end{array}$} & \multirow{2}{*}{$\begin{array}{cc}\text { 流 } & \text { 富 } \\
\text { 水 } & \text { 澡 }\end{array}$} & \multicolumn{2}{|c|}{$2 l / \mathrm{min}$} & \multicolumn{2}{|c|}{$6 l / \min$} \\
\hline & & $1 \mathrm{~cm}$ & $5 \mathrm{~cm}$ & $1 \mathrm{~cm}$ & $5 \mathrm{~cm}$ \\
\hline \multirow{3}{*}{31.5} & カ ス温 ${ }^{\circ} \mathrm{C}$ & 32.3 & 31.9 & 32.2 & 31.6 \\
\hline & 露 点 ${ }^{\circ} \mathrm{C}$ & 31.0 & 31.2 & 31.3 & 31.0 \\
\hline & R.H. 96 & 92.9 & 96.0 & 95.0 & 96.6 \\
\hline \multirow{3}{*}{29.0} & H ス温 ${ }^{\circ} \mathrm{C}$ & 31.7 & 31.7 & 31.1 & 31.0 \\
\hline & 露 点 ${ }^{\circ} \mathrm{C}$ & 30.4 & 30.5 & 29.7 & 30.0 \\
\hline & R. H. 96 & 92.8 & 93.4 & 92.2 & 94.4 \\
\hline \multirow{3}{*}{ 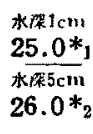 } & H ス温 ${ }^{\circ} \mathrm{C}$ & $30.6 *_{1}$ & $31.5 * 2$ & $29.4 *_{1}$ & $30.1 *_{2}$ \\
\hline & 露 点 ${ }^{\circ} \mathrm{C}$ & 28.1 & 28.9 & 26.8 & 27.7 \\
\hline & R.H. $\mathscr{6}$ & 86.8 & 86.1 & 85.9 & 87.0 \\
\hline \multirow{3}{*}{18.0} & カ ス温 ${ }^{\circ} \mathrm{C}$ & 28.5 & 28.3 & 27.2 & 26.8 \\
\hline & 露 点 ${ }^{\circ} \mathrm{C}$ & 23.3 & 23.3 & 21.6 & 22.2 \\
\hline & R. H. 96 & 73.5 & 74.3 & 71.5 & 75.9 \\
\hline \multirow{3}{*}{13.0} & カ九温 ${ }^{\circ} \mathrm{C}$ & 27.3 & 26.8 & 23.4 & 22.3 \\
\hline & 昸点 ${ }^{\circ} \mathrm{C}$ & 19.4 & 19.6 & 17.2 & 18.8 \\
\hline & R.H. $\%$ & 62.1 & 64.7 & 68.2 & 80.6 \\
\hline \multirow{3}{*}{3.6} & ガス温 ${ }^{\circ} \mathrm{C}$ & 26.3 & 25.4 & 20.7 & 17.8 \\
\hline & 点 ${ }^{\circ} \mathrm{C}$ & 15.8 & 17.3 & 13.8 & 14.5 \\
\hline & R. H. 96 & 52.5 & 60.9 & 64.6 & 81.0 \\
\hline
\end{tabular}

第 4 表水梁の影辢

\begin{tabular}{|c|c|c|c|c|c|c|c|c|}
\hline 水 & 流量 $l / \mathrm{min}$. & 1 & 2 & 3 & 4 & 5 & 6 & 7 \\
\hline 樑 & $\begin{array}{l}\text { 給 鼬 前 } 9 \\
\text { 前 }{ }^{\circ} \mathrm{C}\end{array}$ & 23.4 & 23.4 & 23.3 & 23.2 & 23.1 & 23.0 & 22.9 \\
\hline \multirow{3}{*}{$1 \mathrm{~cm}$} & ガ 温 ${ }^{\circ} \mathbf{C}$ & 23.3 & 23.2 & 23.0 & 22.8 & 22.7 & 22.6 & 22.4 \\
\hline & 露 $\quad$ 点 ${ }^{\circ} \mathrm{C}$ & 22.0 & 21.8 & 21.6 & 21.4 & 21.4 & 21.4 & 21.4 \\
\hline & R. H. $\mathscr{6}$ & 92.4 & 91.8 & 91.8 & 91.8 & 92.3 & 92.9 & 94.0 \\
\hline \multirow{3}{*}{$3 \mathrm{~cm}$} & H 温 ${ }^{\circ} \mathrm{C}$ & 23.3 & 23.1 & 22.8 & 22.6 & 22.4 & 22.2 & 22.1 \\
\hline & 点 ${ }^{\circ} \mathrm{C}$ & 22.1 & 22.0 & 21.8 & 21.7 & 21.6 & 21.5 & 21.5 \\
\hline & R. H. $\mathscr{6}$ & 92.9 & 93.5 & 94.0 & 94.6 & 95.2 & 95.8 & 96.4 \\
\hline \multirow{3}{*}{$5 \mathrm{~cm}$} & ガス温 ${ }^{\circ} \mathrm{C}$ & 23.0 & 22.8 & 22.7 & 22.5 & 22.4 & 22.3 & 22.1 \\
\hline & 蕗 点 ${ }^{\circ} \mathrm{C}$ & 22.3 & 22.2 & 22.1 & 21.9 & 21.8 & 21.7 & 21.7 \\
\hline & R. H. $\mathscr{6}$ & 95.8 & 96.4 & 96.4 & 96.3 & 96.4 & 96.3 & 97.5 \\
\hline \multirow{3}{*}{$10 \mathrm{~cm}$} & H 又温 ${ }^{\circ} \mathrm{C}$ & 22.6 & 22.6 & 22.6 & 22.4 & 22.3 & 22.1 & 22.0 \\
\hline & 露 点 ${ }^{\circ} \mathrm{C}$ & 22.2 & 22.1 & 22.0 & 21.8 & 21.7 & 21.6 & 21.6 \\
\hline & R. H. $\mathscr{6}$ & 97.5 & 97.0 & 96.4 & 96.4 & 96.3 & 97.0 & 97.6 \\
\hline
\end{tabular}


2つの影整が加わつた結果となるので測定值の詳細 は省く。

\section{4、水深の站素}

第 4 表付水樑の変化か，ガス温，露点，関係湿度 によ゙のように影翠するかを実験したすのである，使 用した給湿器は直径 $1 \mathrm{~mm}$ の孔 1 個から横向きに bubble するもので, この時の水温は20.7 ${ }^{\circ} \mathrm{C}$ であつ た，水深が大になるほど気泡が水の影整を受ける時 問が長いので，当然ガス盜は水温に近ずき，湿度は 上昇している．前節第 3 表，後節第 5 表，第 6 表で あ同様の関保は明らかである.

極端に水深が大きいと（例えば $50 \mathrm{~cm}$ 以上もあれ ば)、ガス温, 気温, 水温の3者がほぼ一致して100 \%飽和になるが，医学的実用の観点加ら見れば水㳜 が 8〜10cm 以上飞あなると実效上の差は少なくな るとしてよい，反対に浅いと（特に $1 \mathrm{~cm}$ 以下では） 少しの水深の差がかなりの差を生ずる，(ただし実 際には後述の水面上の泡立ちや飛沫がこの差をある 程度相殺していることがわかる).
気泡の表面は，気体に比べて圧倒的に熱容量の大 きい周囲の水の沮度に近くなりそこで水の蒸発がお こると考えられるか，気泡の内部の温度は浅い所か ら浮上する短い時間の間には余り変らず，湿度も内 部まで均一化するのには時間かかかかる。とれら気泡 内外の変化の詳細については測定の方法がなく，実 際に問題になるのは全体が水面上に出て湿合したが スについてであり，その溪度は給湿器に入る前のガ ス温之水温との中間にあり，露点はガス滥よりも低 いか水洫よりは高く㫣低くもなりうる．ただし水温 についても bubble している所自体のむのは測定で きないので，まわりの水の温度を椡つて代表した。 测定する場所によりある程度の差を生じるのは避り られないか，なるへく平均した值を示すように工夫 した.

\section{5. 孔の方向の影䊦}

ガスの噴出孔が同し水深にあつてあ，それか下へ 向いているならば，啫出されたガスは更に梁くもく つてから浮上してくるので，橫问きに噴出される場

第 5 表 孔の方向の影

\begin{tabular}{|c|c|c|c|c|c|c|c|c|c|c|}
\hline \multirow{2}{*}{$\begin{array}{l}\text { 水 } \\
\text { 深 }\end{array}$} & \multirow{2}{*}{$\begin{array}{l}\text { 孔 } \\
\text { 足 } \\
\text { 㨁 } \\
\text { 径 }\end{array}$} & 孔 の方 向 & \multicolumn{2}{|c|}{ 下 } & \multicolumn{2}{|c|}{ き } & \multicolumn{2}{|c|}{ 橫 } & \multicolumn{2}{|c|}{ き } \\
\hline & & 流 $l / \mathrm{min}$. & 1 & 3 & 5 & 7 & 1 & 3 & 5 & 7 \\
\hline \multirow{4}{*}{$1 \mathrm{~cm}$} & \multirow{4}{*}{$8 \mathrm{~mm}$} & $H$ ス 温 ${ }^{\circ} \mathbf{C}$ & 27.8 & 27.6 & 27.2 & 26.9 & 28.0 & 27.5 & 26.8 & 26.5 \\
\hline & & 露 点 ${ }^{\circ} \mathrm{C}$ & 22.1 & 21.5 & 21.1 & 20.8 & 20.9 & 20.7 & 20.2 & 20.0 \\
\hline & & R. H. & 71.1 & 69.4 & 69.3 & 69.3 & 65.3 & 66.5 & 67.2 & 67.5 \\
\hline & & 給韲前カス温 & \multicolumn{4}{|c|}{ 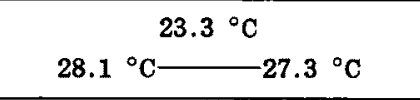 } & \multicolumn{4}{|c|}{$24.8^{\circ} \mathrm{C}$} \\
\hline \multirow{4}{*}{$5 \mathrm{~cm}$} & \multirow{4}{*}{$8 \mathrm{~mm}$} & カ 温 ${ }^{\circ} \mathrm{C}$ & 28.0 & 27.6 & 27.4 & 27.0 & 27.5 & 27.0 & 26.6 & 26.4 \\
\hline & & 露 点 ${ }^{\circ} \mathrm{C}$ & 22.5 & 22.1 & 21.8 & 21.5 & 20.9 & 20.7 & 20.5 & 20.4 \\
\hline & & R. H. $\mathscr{6}$ & 72.1 & 72.0 & 72.3 & 71.4 & 67.4 & 68.4 & 69.2 & 69.6 \\
\hline & & 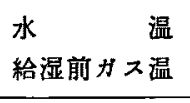 & \multicolumn{4}{|c|}{$23.3^{\circ} \mathrm{C}$} & \multicolumn{4}{|c|}{$24.8^{\circ} \mathrm{C}$} \\
\hline \multirow{4}{*}{$1 \mathrm{~cm}$} & \multirow{4}{*}{$\begin{array}{l}5.4 \\
\mathrm{~mm}\end{array}$} & H ス 温 ${ }^{\circ} \mathrm{C}$ & 27.4 & 26.9 & 26.6 & 26.5 & 28.3 & 28.0 & 27.4 & 27.2 \\
\hline & & 蕗 点 ${ }^{\circ} \mathrm{C}$ & 22.9 & 22.7 & 22.4 & 22.3 & 22.6 & 22.5 & 22.1 & 21.8 \\
\hline & & R. H. & 76.4 & 77.8 & 77.7 & 77.8 & 71.3 & 72.1 & 72.8 & 72.4 \\
\hline & & $\begin{array}{l}\text { 水 } \text { 温 } \\
\text { 給湿前ガス温 }\end{array}$ & \multicolumn{4}{|c|}{$27.0^{\circ} \mathrm{C} \mathrm{C}$} & \multicolumn{4}{|c|}{$24.7^{\circ} \mathrm{C}$} \\
\hline \multirow{4}{*}{$3 \mathrm{~cm}$} & \multirow{4}{*}{$\begin{array}{l}5.4 \\
\mathrm{~mm}\end{array}$} & $H 又$ 温 ${ }^{\circ} \mathrm{C}$ & 27.1 & 26.7 & 26.4 & 26.3 & 28.3 & 28.0 & 27.4 & 27.2 \\
\hline & & 蕗 点 ${ }^{\circ} \mathrm{C}$ & 23.0 & 23.1 & 22.7 & 22.5 & 22.7 & 22.6 & 22.1 & 21.9 \\
\hline & & R. H. $\%$ & 78.3 & 80.6 & 80.1 & 79.6 & 71.7 & 72.5 & 72.8 & 72.9 \\
\hline & & $\begin{array}{l}\text { 水 温 } \\
\text { 給湿前カ ス温 }\end{array}$ & \multicolumn{4}{|c|}{$24.0^{\circ} \mathrm{C}$} & \multicolumn{4}{|c|}{$24.7^{\circ} \mathrm{C}$} \\
\hline
\end{tabular}


合にくらべて，気泡が水中にある時間がかなり長く なる，第 5 表はその関係を示す，R.H. を比較して みれば，下向きは横向きより全般に高いことがわか る.ただしこれはれが1個の場合の結果であつて, 多数の孔が全部真下に向いていると，生じた気泡が 同方向に集まつて瘦合し，大きな気泡を生じるので，

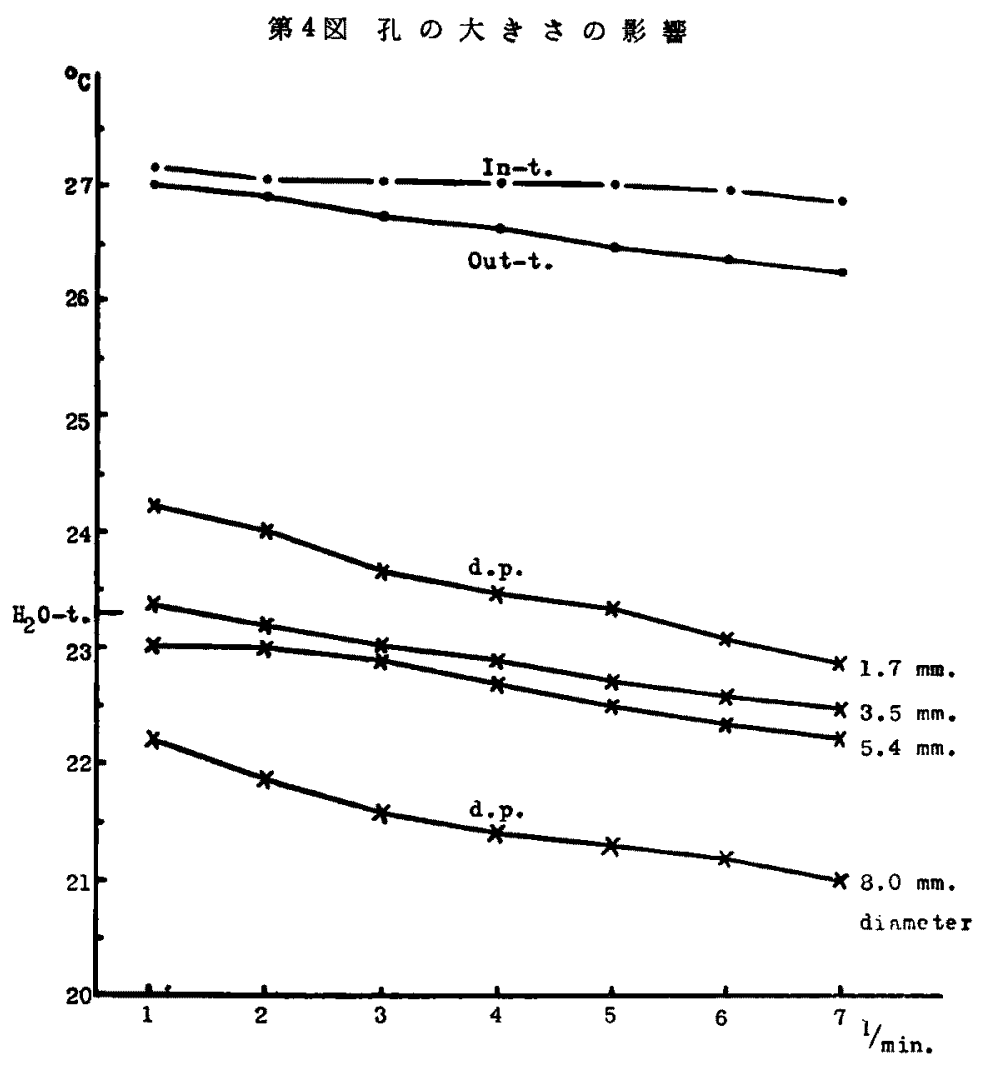

$\mathrm{O}_{2}$-flow
かえつて効率が落ちる事実がある. 多数の孔から噴 出した気泡か四方へまんべんに拡がつて塊まらない ように，孔の方向を放射状に斜め下に向ける必要が ある。

6. 孔の大きさの彭醅

做出孔が小さいほど，それから出る気泡す小さく なるので, 給湿効果が良 い. 第 4 図は 4 種の異な る内径のパイプの先から 下向きに bubble さした 時の露点の変化を示す。 内径すなわち喷出孔が小 さいはど露点は上袒して いる. この時の水深は $3 \mathrm{~cm}$, 水温は $23.3^{\circ} \mathrm{C}$ て 一定,ガス温は給湿前 (In-t.)，給湿後 (Out-t.) ともに4種のパイプでの 差はほとんどない，同様 の関係は，前節第 5 表の R. H. を比烄してもうか がえる。

7. 孔の数による影素

同じ大きさの貲出孔の 数を増した実験を第 6 表 (第 4 表とも比較) に示 す. 孔はいずれも直径 $1 \mathrm{~mm}$, 水温 $20.4^{\circ} \mathrm{C}$, 給湿 前のガス温は $20.6^{\circ} \mathrm{C}$ か ら22.4ㅇ C間であつた。 孔の数が多いと幾分給湿

第 6 表 孔 の 数 の 喝 響

\begin{tabular}{|c|c|c|c|c|c|c|c|c|c|c|}
\hline \multirow{2}{*}{\multicolumn{2}{|c|}{$\begin{array}{l}\text { 孔 } \\
\Phi \\
\text { 数 }\end{array}$}} & \multirow{2}{*}{$\frac{\text { 水 深 }}{\text { 流 } l / \text { min. }}$} & \multicolumn{4}{|c|}{$1 \mathrm{~cm}$} & \multicolumn{4}{|c|}{$3 \mathrm{~cm}$} \\
\hline & & & 1 & 3 & 5 & 7 & 1 & 3 & 5 & 7 \\
\hline \multirow{3}{*}{2} & \multirow{3}{*}{ 個 } & カ ス 温 ${ }^{\circ} \mathbf{C}$ & 22.5 & 22.2 & 22.0 & 21.8 & 22.0 & 21.8 & 21.7 & 21.5 \\
\hline & & 露 点 ${ }^{\circ} \mathrm{C}$ & 21.3 & 21.1 & 20.9 & 20.6 & 21.2 & 21.0 & 20.9 & 20.7 \\
\hline & & R. H. $\mathscr{6}$ & 92.9 & 93.5 & 93.4 & 93.0 & 95.0 & 95.2 & 95.2 & 95.2 \\
\hline \multirow{3}{*}{3} & \multirow{3}{*}{ 個 } & カ ス 温 ${ }^{\circ} \mathbf{C}$ & 22.4 & 22.1 & 21.9 & 21.7 & 21.9 & 21.7 & 21.4 & 21.3 \\
\hline & & 簬 点 ${ }^{\circ} \mathrm{C}$ & 21.3 & 21.3 & 21.1 & 21.0 & 21.2 & 21.0 & 20.8 & 20.7 \\
\hline & & R. H. $\%$ & 93.5 & 95.2 & 95.2 & 95.8 & 95.7 & 95.8 & 96.4 & 96.3 \\
\hline \multirow{3}{*}{8} & \multirow{3}{*}{ 個 } & H ス 温 ${ }^{\circ} \mathrm{C}$ & 22.4 & 22.0 & 21.8 & 21.6 & 21.9 & 21.6 & 21.4 & 21.3 \\
\hline & & 露 点 ${ }^{\circ} \mathrm{C}$ & 21.6 & 21.4 & 21.2 & 21.2 & 21.3 & 21.1 & 20.9 & 20.9 \\
\hline & & R. H. $\not 6$ & 95.2 & 96.3 & 96.4 & 97.4 & 96.4 & 96.9 & 96.9 & 97.5 \\
\hline
\end{tabular}


奻果が上つているが，とれは小さい1個のれから高 流量のガスが㖕出するときには，止がかかるから， 生ずる気泡が大きくなるためと解せられる，反対に 多数の孔があれば高流量になるにつれて噴出に使わ れる孔の数が多くなつて，気泡の大きさは変らない． しかしこの影幚は大きなるのではなく，特に水深が 8cm 以上になつたり，孔の直径が $4 \mathrm{~mm}$ 以上だつた りするとほとんど問題とならなくなる。

6，7，を組み合わして，小さい孔を無数につけて 給湿効果を良くしたものが，エーテル気化器(1．の 3)で既述)である. 水温を一定 $\left(31.0^{\circ} \mathrm{C}\right)$ にして実 験した時の測定値は第 7 表のようであり，低流量は

第 7 表 エーテル気化器（T.I. 敝）の給湿好果

\begin{tabular}{|c|c|c|c|c|c|}
\hline 水深 & 流量 $l / \mathrm{min}$. & 1 & 2 & 6 & 10 \\
\hline \multirow{3}{*}{$1 \mathrm{~cm}$} & ガス温 ${ }^{\circ} \mathrm{C}$ & 31.2 & 31.1 & 30.5 & 30.0 \\
\hline & 露 点 ${ }^{\circ} \mathrm{C}$ & 31.0 & 31.0 & 30.4 & 29.4 \\
\hline & R. H. $\mathscr{6}$ & 98.8 & 99.4 & 99.4 & 96.6 \\
\hline \multirow{3}{*}{$5 \mathrm{~cm}$} & Hス温 ${ }^{\circ} \mathbf{C}$ & 31.2 & 31.2 & 31.0 & 30.8 \\
\hline & 露 点 ${ }^{\circ} \mathrm{C}$ & 30.7 & 30.7 & 30.7 & 30.5 \\
\hline & R. H. $\%$ & 97.1 & 97.1 & 97.7 & 98.3 \\
\hline
\end{tabular}

あちろん高流量にいたるまで常に刘率がよいことが わかるままたチダ Easyflowmeter や汁り簡易 気体流瞦計19）の上うに，流量加增すにつれて水深

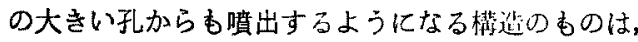
高流量でも簬点の下降が少ないととがわかる。

\section{8. 水の粘性を增す実験}

水ガラスやグリセリンを混ずるととにより水の粘 性を増加すると，気泡が水中にある㭙閌が辰くなり， 給湿效果が良くなるのではないかと考えて，次の実

第 8 表 水の粘性增加の影暂

\begin{tabular}{|c|c|c|c|c|c|}
\hline \multirow{2}{*}{$\begin{array}{l}\text { 流 } \\
\text { 水 } \\
\end{array}$} & \multirow{2}{*}{$\begin{array}{l}\text { 量 } \\
\text { 深 }\end{array}$} & \multicolumn{2}{|c|}{$2 \mathrm{l} / \mathrm{min}$} & \multicolumn{2}{|c|}{$6 \mathrm{l} / \mathrm{min}}$. \\
\hline & & $1 \mathrm{~cm}$ & $5 \mathrm{~cm}$ & $1 \mathrm{~cm}$ & $5 \mathrm{~cm}$ \\
\hline \multicolumn{2}{|c|}{ 水: 水ガラン } & \multicolumn{2}{|c|}{ 露 } & \multicolumn{2}{|c|}{ 点 $\quad{ }^{\circ} \mathrm{C}$} \\
\hline 純 & 水 & 28.5 & 28.6 & 27.9 & 28.4 \\
\hline 4 & • & 28.4 & 28.4 & 27.5 & 28.0 \\
\hline 2 & : & 28.4 & 28.5 & 27.8 & 28.3 \\
\hline 4 & : & 28.4 & 28.4 & 27.6 & 28.0 \\
\hline 1 & : & 28.3 & 28.4 & 27.4 & 28.0 \\
\hline 2 & : & 28.1 & 28.3 & 27.2 & 27.9 \\
\hline \multicolumn{2}{|c|}{ 水 温 ${ }^{\circ} \mathrm{C}$} & \multicolumn{2}{|c|}{28.1} & \multicolumn{2}{|c|}{27.7} \\
\hline \multicolumn{2}{|c|}{$\begin{array}{l}\text { 給湿後 }{ }^{\circ} \mathrm{C} \\
\text { 温 }\end{array}$} & 30.2 & 29.9 & 29.6 & 29.5 \\
\hline
\end{tabular}

験をした．給湿器内の水に，厓々な割合で水ガラス を混じた。

給湿前のガス温は気温と一致して常に $30.8^{\circ} \mathrm{C} て ゙$ あつた，第8表はその笿点の変化を示す。これによ ると，予期に反して粘性加增すにつれて湿度はむし ろ落ちる傾向にある。これの原因については考案で 触れる。

\section{9. 流量その他について}

酸素の流量については，普通酸素治瘄で必要とさ れる籍囲を対象としたが，その影響は前節までのす へての実颀成績から伺いうる，すなわち高流量ほど 露点は一般に下つている。給湿後のガス温も同様に 高流量任ど下つているが，その程度は露点や給湿前 のガス温が高流量で下る程度より大きいことが多い， そこで関係湿度を求めると，高流量で下らずむしろ 上る傾向にあることが多い，乙れは水の蒸発慜の影 然と考えられる。

一方，給湿效果に影響を及ばす他の团子として， 水面上での泡立ちや飛涑がある.これらはとく高 流量で水深が小さいとき著しいので，乙れまでの因 子では給湿効喿が劣ると考えら机る時に，加えつて 給湿効果を上げるのに役立つている．しかし飛沫が 盖出管内まで飛来すると，吸入作険であるので注 意を要する. そのため水面加導出管までは高さ $8 \mathrm{~cm}$ 位, 水面の大きさも約 $30 \mathrm{~cm}^{2}$ 以上必要である.

\section{IV，総括及び考按}

以上のような bubbling による給湿機構を理諭的 に考えると次のようになる。

全く水分を含んでいない酸萦が，水面下 hocm の 所で暁出孔から出て気泡となり，自己の浮力で浮上 を始める. その気泡が水面に達するまでに含む単位 体棈あたりの全水分量を $\mathrm{X}_{\mathrm{wgm}} / \mathrm{cm}^{3}$ とする. 気泡 の形は簡単にするために完全な球形とし, 水深 hocm の所における半径を $\mathrm{a}_{0} \mathrm{~cm}$ ，体積を $\mathrm{V}_{0} \mathrm{~cm}^{3}, \mathrm{~h} \mathrm{~cm} k$ おけるそ机らを $\mathrm{a} \mathrm{cm}, \mathrm{V} \mathrm{cm}$ とすれば。

$$
\mathrm{V}_{0}=\frac{4}{3} \pi \mathrm{a}_{0}^{3} お \text { よび } \mathrm{V}=\frac{4}{3} \pi \mathrm{a}^{3}
$$

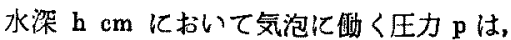

$$
\mathrm{p}=\mathrm{P}+\mathrm{gh}-\frac{2 \mathrm{~T}}{\mathrm{a}}
$$

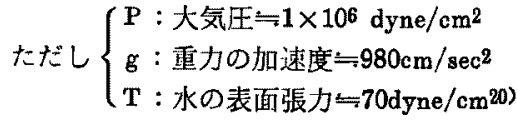

気体は Boyle の法則により，

$$
\text { औ. } \pi \mathrm{a}^{3}=\frac{\frac{4}{3} \pi \mathrm{a}_{0}^{3}\left(\mathrm{P}+\mathrm{gho}_{0}-\frac{2 \mathrm{~T}}{\mathrm{a}_{0}}\right)}{\mathrm{P}+\mathrm{gh}-\frac{2 \mathrm{~T}}{\mathrm{a}}}
$$


一般に h は $10 \mathrm{~cm}$ 以下，a は $0.1 \sim 1.5 \mathrm{~cm}$ 位で使用 するので, $\mathrm{P} \gg \mathrm{gh}-\frac{2 \mathrm{~T}}{\mathrm{a}}$ であり，(3)より て良い。

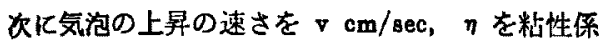
数（水では $20^{\circ} \mathrm{C} て ゙ 1 \times 10^{-2} \mathrm{gm} / \mathrm{sec} \cdot \mathrm{cm}$ ) 20$)$ とし, 水 による抵抗 R は Stokes の法則に従うとすると、

$$
R=6 \pi \text { mav }
$$

一方泡に㗢〈浮力 $\mathrm{F}$ は， $\mathrm{F}=\rho \mathrm{V}_{\mathrm{g}}=\frac{4}{3} \pi \mathrm{a}^{3} \mathrm{~g}$

ただし・p：水の密度 $=1 \mathrm{gm} / \mathrm{cm}^{3}$

$\mathrm{F}=\mathrm{R}$ であるので(4)，(5)より

$$
\nabla=\frac{2 g a^{2}}{9 \eta}(\nabla は 一 \text { 定 })
$$

気泡の上异所要時間は

$$
t=\frac{h_{0}}{v}=\frac{9 \eta h_{0}}{2 a_{0}^{2}}
$$

気泡周用の水面から気泡内へ単位時間にはいりと む水蒸気の量を $\mathrm{W} \mathbf{g} \mathbf{m}$ とする,

$$
\begin{aligned}
& W=\frac{d\left(V_{X}\right)}{d t}
\end{aligned}
$$

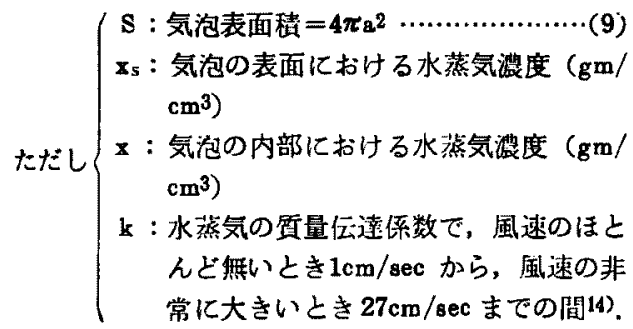

(7), (8) より $\frac{\mathrm{dx}}{\mathrm{dt}}=\frac{\mathrm{Sk}\left(\mathrm{x}_{\mathrm{s}}-\mathrm{x}\right)}{\mathrm{V}}$

䞍分して $\int-\frac{d x}{\left(x_{s}-x\right)}=\int-\frac{S k}{V} d t$

$$
\begin{aligned}
& \therefore \log \left(x_{s}-x\right)=-\frac{S k}{V} t+C \\
& \therefore x_{s}-x=e^{-\frac{s k}{v} t+C}=C^{\prime} e^{-\frac{s k}{V} t}\left(\because C^{\prime}=e^{C}\right)
\end{aligned}
$$

とてで $\mathrm{t}=0$ のときは $\mathbf{x}=0$ であるから， $\mathbf{x}_{\mathrm{n}}=\mathrm{C}^{\prime}$.

$$
\begin{aligned}
& \therefore x_{n}-x=x_{s} e^{-\frac{s k}{v} t} \\
& \therefore x=x_{s}\left(1-e^{-\frac{s k}{v} t}\right)
\end{aligned}
$$

(10) K (1)，(6)，(9) を代入すると,

$$
x_{w}=x_{s}\left\{1-\exp \left(-\frac{27 \eta_{h_{0}}}{2 \mathrm{ga}_{0}^{j}}\right)\right\}
$$

これに g，クを代入すると

$$
x_{w}=x_{s}\left\{1-\exp \left(-\frac{138 \mathrm{kh}_{0}}{106 \mathrm{a}_{0}^{3}}\right)\right\}
$$

例えば $\mathrm{k}=5$ とし、年2.7であるから

$$
x_{w} \fallingdotseq x_{s}\left(1-2.7^{-\frac{138 h_{0}}{106 a_{0}^{3}}}\right) \text { となる. }
$$

上の式から考えられることは，次のようである．

(A) $x_{w}$ は $x_{s}$ に比例する， $x_{n}$ は水の温度之気 泡内部のガスの温度の中間にある温度の飽和水蒸気 濃度（絶対湿度）であるから，得られるガスの絶対 湿度はその原料である水と酸菜ガスの温度に最も支 配されるととを意味する，通常の使用状態では，ボ ンベから出る酸素ガスの湿度はそこの気温に近く, 水温はそれよりかなり低いととが多いが，できるだ り水を気淐近くまで温めて用いるのが良い，気温以 上に高い温度の湯を用いても，患者に届くまでの導 管を温めないかきりりはの壁に蕗の凝結を見るばか りであり，また湯の温度も気化熱によりたやすく気 温まで下るでおろう.そこで他に支障がないかぎり なるへく室温を高く保ち、給湿器内の水温もできる だけそれに近く保つのが, 最も実際的で有奻な万法 と思われる。それには気化瓶を熱伝苸率のよいもの にする必要があり，表面皘を大きくしたり金属性( 特に鉰性）にする工夫が考えられる．とのことは給 湿器の効率が良く，高流量のガスを用いるほど重要

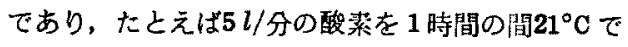
完全飽和に保ちながら用いるためには，約5.5gmの 水加䔲発し, $3190 \mathrm{Cal}$. の熱量加必要である（この 温度におりる水の気化熱：580Ca1.）。乙れが周囲か ら直ちに禣えないと水温が下降し，ある程度まで気 温との差が大きくなると平衡に達するわりであるが， 分厚いガラス瓶などで実験するととの差は $10^{\circ} \mathrm{C}$ 以 上に及ふてとがある。とくに医学的害用すなわち Humidity therapy では, 気道内における体温に対 しての問題である加ら，第 5 図・C に示すように $37^{\circ} \mathrm{C}$ に対する R. H. を考えてみ玌は，目標はその ガス自体の R.H. より露点そのあのをあげること であり，それにはこの室湿および水温の問題加最も 決定的であることはおのずから明らかである.

(B) $b_{0}$ すなわち気泡が最も梁部にあるときの水 深が大きいほど， $\mathbf{x}_{\mathrm{w}}$ は大となる，乙の $\mathrm{h}_{0}$ の変化 による影㑭は，hoが小さい間ほど大きく帮き，ある 程度深くなると小さい bo の差による影然は少なく なる.つまり害際には水潹 $10 \mathrm{~cm}$ あおればに活目的 を達するわけである。

（C） k（質量伝達係数)か大きいほど，つまり気 泡が勢いよく泡立ち渦䓡くほど効率がよい：とれに はガスの流量と孔の数，大きさが関係する.

（D） a (気泡の半烽）が小さいほよ゙，xw は大で 
第 5 図露点から次の4つのととを求めるための成俰图（原図）

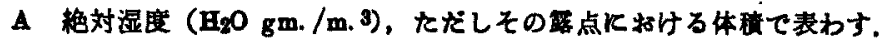

B 水䯂気压 $(\mathrm{mmH})$.

C 体温 $\left(37^{\circ} \mathrm{C}\right)$ K対する関係湿度 (R. H.

D 大気压 $\left(760 \mathrm{~mm} \mathrm{Hg}_{\mathrm{g}}\right)$ て水蒸気が占める Vol. $\%$.

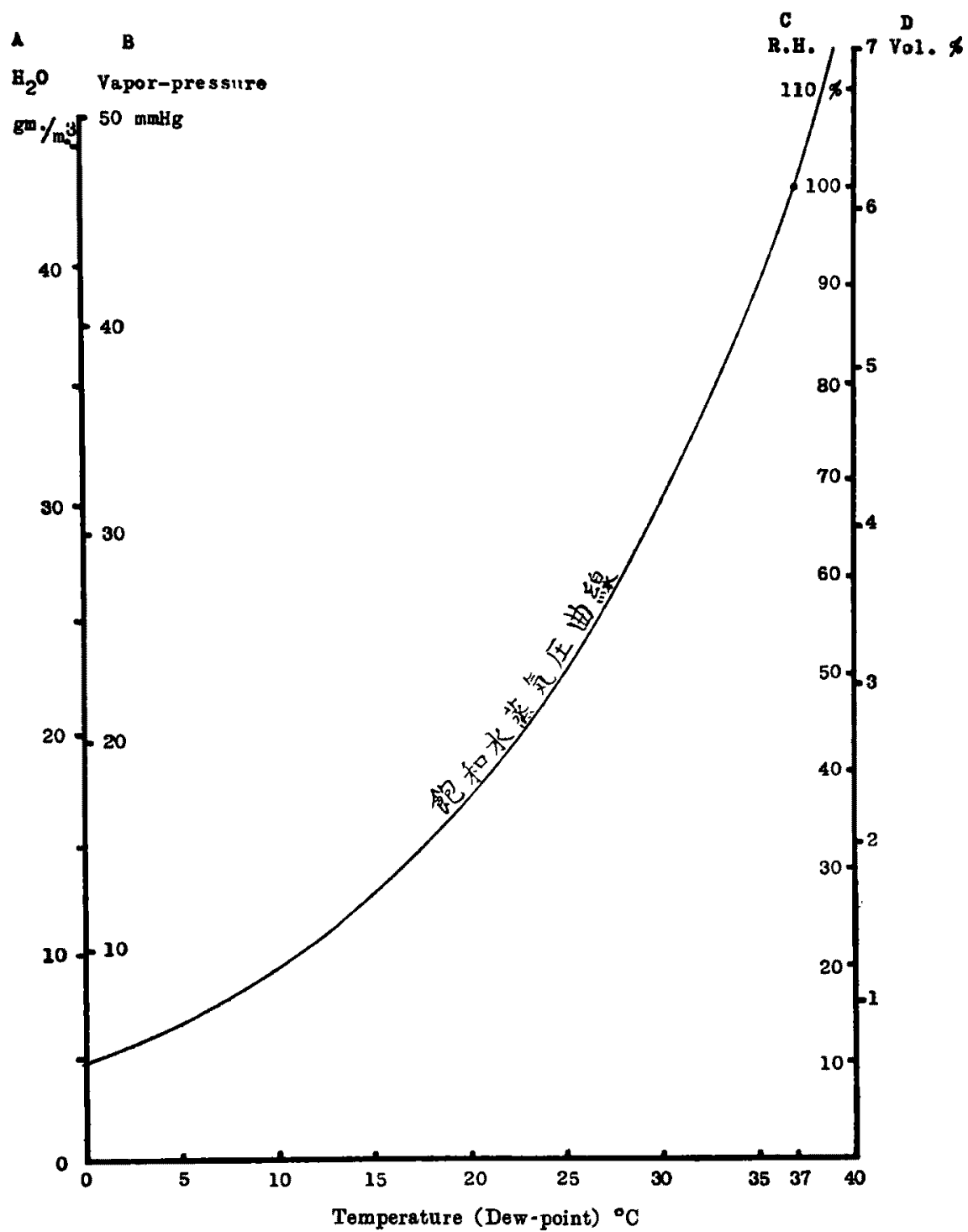

ある、、は3乘であるから大きな影锌があるが，乙 れをきかるあのはます噴出れの大きさである。しか し酸菜流量が大であると孔から喷出するときにより 大きい圧をうけるので，同し孔からですきい気泡 を生ずる．また噴出孔の数が少ないとやはり同様に 圧かかかつて気泡は大きくなる。一方孔がある程度 以上大きくても圧が少ないと，気泡は孔一ぱいにな
つて出ててないし，またあまり大きな気泡が生じて もおのずから割れて小さくなりやすいてとも锤察さ れている.

このように孔の大きさや数の問题は非常に複維で あり，必ず大小不同の泡方涅つて生じるが，全体之 してのガスの湿度は，大きい気泡の低い蚫和度に体 栍の関係加らきく左右されるので，なるべく均一 
の小さい泡をつねに発生できる気化器,つまり無数 の微小な孔があいたものが理想と云うととになる。 てれを简単に水蘶気の蒸発面積の関係加計算する と、気泡の半径がたとえば $1 / 10$ の1,000個の小さい 泡になつたとすると，その総面積は10倍になる。つ まり蒸発面積は気泡の半径に反比例する。

（E） $\eta$ (水の粘性) が増すほど, 気泡がゆつくり 浮上するので水に触れる時間が長くなり， $\mathbf{x}_{\mathbf{w}}$ も増

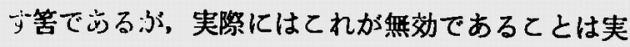
酫で示した。この原因としては上記の影帮よりも。 （1）粘性を增すために水ガラスヤグリセリンをかな りの量を混ずるととにより飽和水蒸気圧が下る.

(2) 水の蒸発速度 (拡散係数) が隇少する. (3) 気 泡が小さく割れず (aが)，勢いよく泡立ため（k が小)などのマイナスの影掣の方がより大きいから と考えられる.

ての理論式で触れなかつたものとして，水面上に 泡が残りあふくくとなることや水滴が飛散するために， ガスが水に触れる時間が長くなり，湿度をあげるの 飞役立つている事実む見逃せない，乙の効果は水中 での飽和が不十分な時にとくに有効であると考えら れる.

以上のような近似的理論では，大体の傾向を伺う には役立つても，乙の複雑な現象の実態は解らない ので，前記のような実験によつたわけである．実験 は各因子が連続的に変化し無数の組合せで可能なわ けであるが, 記载の都合上測定値の呈示は実際に行 つた多数の実験のうち代表例のみにとどめた。また 平均值を求めて代表さすことはてのような実験の性 質上不可能である. しかしそれら多数の類似した実 禹の結果も，すへてててに示した代表的数值や意見 を支持しており，医学的実用上参考になるようなて とは以上に十分示されていると思う。

呼吸之湿度との関係の詳細については別に発 表12223)するが，吸気が十分な湿度をすつととが 気道粘膜の䱂きを正常に保つうえにいかに重要 であるかは一般に良く知られている。給湿療法 は，呼吸器系の合併症の予防や治療には古くか ら用いられて来た。 その主な作用機序は, 気道 の分泌物の粘性を減じ，䄉毛運動を活潑にして 喀痰を容易にすることである778). 日常生活です 乾燥した気体は気道に刺戟的で, 反刘に湿つた 空気を吸うと気持の良いととを誰であ経験して いる. 風呂場の湯気や Nebulizer からのいわゆ るAerozol など過飽和な状態がむしろ気道粘膜 にとつては快的でさえありうる.人間において
は，呼吸におりる水分苜散は体温調節上重要でなく。 気道粘膜は水蒸気飽和の気体に何時も触れていると とがしろ好ましいと考えられる。つまり，吸気の 体温に対する関係湿度が高けれぱ，気道粘膜は呼気 相ではすつと飽和したガスに触れるわけで，反対に 吸気が $37^{\circ} \mathrm{C}$ での飽和に遠いと，それ自体刺戟的で あるばかりでなく，呼気の湿度もかなり下るととが。 著者の測定で観察されている12)。このととは, 気管 内㨉管や吹送法 (Insufflation) による麻䣦，また は経鼻酸素投与 (Nasopharyngeal catheter による) などの場合のように，鼻腔や口腔の Air-conditioning が除去される場合には，ガスが直ちに気道粘膜に蜰 れるので，とくに重要である，高流量を吹送する場 合にみられる鼻腔や咽頭内の苦痛や乾燥も, 給湿器 の水温を高く保ち，ガスに十分な給湿保温を与えれ， ば除去することができる。 このととは，笑気やエー テルなどを用いて，それらの気化熱のために吹送ガ スの温度が非常に下る場合には，ぜ必要である。 冷い部屋ではいか給湿器の効率が良くても，水温， ガス温ともに低いので，体温に対してははるかに低 い湿度のガスを送ることになる（第 5 図参照）、給 湿器全体を適当に加温するととはかなりの困難を伴 うので, 通常室全体を温くし, 給湿器内の水温も室 温に近く保つ方法を取るが，ての場合体温調節のた めに室の温度はあまり上らぬ方が望ましい，著者は， 従来のガラス製給湿器の多くが非常に効率が悪いこ とを発見し，薬の空缶を利用して手軽で効率の良い 給湿器を自作した. てれは直径約 $8 \mathrm{~cm}$ ，高さ約 $20 \mathrm{~cm}$. の金属性円筒に水を $2 / 3$ ほど入れ，その底近くで直 径 $0.7 \mathrm{~cm}$ の孔20個加ら bubble させるもので, $5 l /$ 分 以上の高流量で長時間使用しても水温は室温より $1.5^{\circ} \mathrm{C}$ 以上下らず，その温度でほぼ飽和した humi-dified gas を得るととができる(第6図).

第 6 四改良された給湿器, 試作品の 1 例

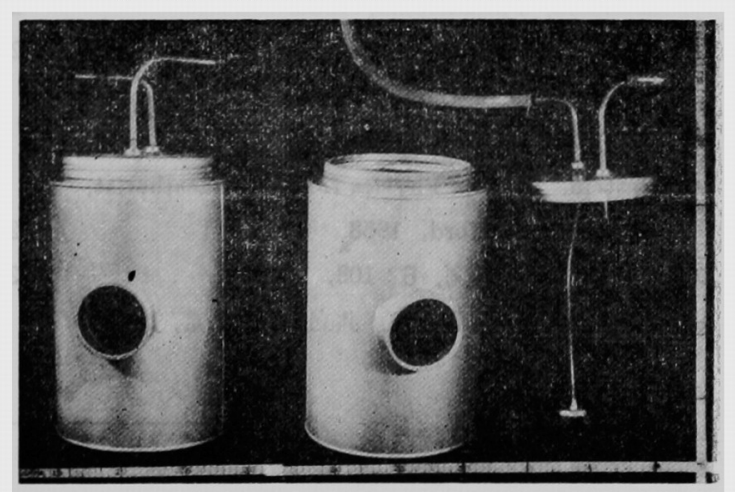


なお，以上は Bubble-type の給湿器化つて述へ たがささらに積杪的に過蚫和のガスを作つて給湿す る必要がある場合には，Mechanical humidifier7) Jet Nebulizer21222) のような形式によらねばならな 心，著者す Nebulizer を麻醉や酸䋕治爒に実用する ことを現在研究中である.

\section{V. 轺 論}

光電管式自動露点計と熱電対を用いて，Bubbletypeの給湿器を中心にその給湿効果を調べた，従 来習惯的に用いられている方法を実測してみると， 非常に不完全な点が多いので，給湿機構に含まれる 各因子を分柝的に調查し，次のような結諭をえた。

(1) 給湿器仙いるカ゚スの温度および秴湿器内の 水の温度を高く保つことが，給湿効果を上げるため 化最も重要である．医学的実用上では，部屋を温く して，給湿器内の水温も室温に近くなるように銅製 容器を用いると良い.

（2）ガスの㖵出孔が小さくて数が多いほど良い． 直径が $1 \mathrm{~mm}$ 以下の孔が10個以上すあれば $8 l /$ 分位 の高流量でも給湿効率が良い。

\section{文}

1）均手邦夫，奥田節夫：応用物理。 $21: 397,1952$.

2) 須田晥次：海洋科学。古今鈷院, 東京, 1943.

3) Levenspiel, O. : Industr. engng. Chem. 51 : 787, 1959.

4) Luchsinger, W. : Kolloid-Z. $81: 180,1937$.

5) Eckert, E. R. G. : Introduction to the Transfer of Heat and Mass. McGraw-Hill, New York, 1950.

6) Humphereys, W. J. : Physics of the Air. McGraw-Hill, New York, 1960.

7) A. M. A. : Fundamentals of Aneshtesia. Saunders, Philadelphia, 1955.

8) Adriani, J. : Chemistry of Anesthesia. C. C. Thomas, Springfield, 1956.

9) Macintosh, Sir R., Mushin, W. W. and Epstein, H. G. : Physics for the Anaesthetist, Blackwell, Oxford, 1958

10）小林寿太郎：計剆， 6:103， 1956.

11) 木谷要一：湿度测定法。共立出版, 東京, 1944.
（3）水深を增すにど良い，約 $10 \mathrm{~cm}$ すあれば十分 てある。

（4）噴出孔を下えむけて bubble さすと，横向き より効率がよい，ただし孔が多数の特は，泡か四方 に喷出して酥合しないように，斜下向きにする。

（5）水ガラスなどを混して水の粘性を增してる効 率は良くならない。

（6）高流量になると好率がお゙ちろので，以上の点 にとくに注意を要する.

（7）水面上での泡立ちゃ，飛沫は，給湿効果を㭪 うのにかなり役立つている.

（本研究飞対して御指紫，御校阅をたまわつた凧 山大学医学部砂田煇武教授，理学部坂手邦夫助授 に深謝する.)

（本論文の要旨山，第 1 回日本麻酔学会関西地方 会に拓いて，またその一部は第35回日本医科器械学 会紷会，第35回中国，四国外科整形外科学会，第23 回岡山外科会においてそれぞれ甡表した).

献

12) 佐藤暢：医科器械学雑誌. $30: 4,1960$.

13）佐藤蜡：医学と生物学. $54: 77,1960$.

14）圾手邦夫：応用物理. (I) $27: 351,1958$. (II) $27: 357,1958$. (III) $28: 451,1959$.

15）坂手邦夫，中岾哲朗：計湘，5:444，1955. 8 : $399,1958$.

16）坛手邦夫，中㕷哲朗：化学工学. $22,298,1958$.

17）场手邦夫：山陽技術雑誌. 11：147，1957.

18）日本気象学会：気象常用表. 地人夆館, 東京, 1949.

19）佐藤太一郎：麻䣲。 $8: 854,1959$.

20）芝笔吉：物理常数表，岩波，東京，1944.

21) Berman, R. A. : Personal communication, Annual meeting of the American Society of Anesthesiologists て1960年10月に発表, Anesthesiology K揭栈予定.

22) Wylie, E. : Personal communication.

23）佐藤啺：Acta Medicinae Okajama K揭裁予定. 


\title{
Studies on Respiratory Humidity : Efficiency of Humidifiers
}

\author{
By \\ Toru Sato \\ 2nd Department of Surgery, Okayama University, Medical School \\ (Director: Prof. Terutake Sunada)
}

Adequate humidification of inhaling gases is important for the normal functioning of the respiratory tract. Humidification facilitates expectoration, inhibits the onset of respiratory complications. and prevents them from getting worse. It is especially important in the care of postoperative patients or patients who are under oxygen therapy. There are many types of humidifiers currently being used, but no reports have appeared in the literature on their efficiency.

An improved photo tube dew.point hygrometer was used for measuring humidity, which was shown on an electronic recorder automatically and continuously. The temperatures of gases before and after humidification, of water in humidifiers, and of the environment air were measured with thermocouples simultaneusly.

A number of experiments were done under varying conditions to evaluate how the efficiency of a bubble-type humidifier is influenced by factors such as: (1) the environment temperature, (2) temperature of gas before it enters the humidifier, (3) temperature of water in it, (4) depth of water for bubbling, (5) number, size and directions of holes from which oxygenbubbles emanate, (6) flow of oxygen, (7) viscosity of water, etc.

The following factors were found to increase the efficiency of humidifiers, experimentally and also theoretically, and were discussed from the standpoint of practical application.

(1) Maintaining temperatures of the inlet flow of oxygen, which was the gas used in most cases, and of the water in the humidifier as high as possible. This is the most obvious factor seen from a clinical standpoint. Copper water containers are recommended instead of glass containers, making it possible to maintain the water temperature very close to the environment temperature. The environment should also be kept sufficiently warm.

(2) Smaller size and increased number of holes (over ten holes with a diameter of less than $1 \mathrm{~mm}$.) can make good humidification, even with high flow.

(3) Bubbling through increased water depth (over $10 \mathrm{~cm}$. of depth) is recommended.

(4) Downward direction of holes is recommended. But, if there are many holes, they should be directed somewhat diverted to lateral so that bubbles radiate in all directions.

(5) Increased viscosity of water is not useful for better humidification.

Also, the effect of foaming and spraying over the water surface was obserbed. 